\title{
Mutational Analysis of the 5' Noncoding Region of the Bcl-6 Gene in Primary Gastric Lymphomas
}

\author{
Jai Hyang Go, M.D., Woo Ick Yang, M.D., Howe J. Ree, M.D. \\ Department of Pathology (JHG), Dankook University College of Medicine, Cheonan; and Department of \\ Pathology (WIY), Yonsei University College of Medicine; and Department of Diagnostic Pathology (HJR), \\ Samsung Medical Center, Seoul, Korea
}

Bcl-6 mRNA and protein are frequently expressed in the transformed counterparts of the germinal center B-cells, diffuse large B-cell lymphoma and follicular lymphoma, irrespective of the gene rearrangements. Most of the primary gastric lymphomas are thought to be of mucosa-associated lymphoid tissue (MALT) origin, and neither bcl-6 gene rearrangement nor protein expression is found in low-grade gastric lymphomas of the MALT type as in normal marginal zone cells. However, bcl-6 protein expression was identified in highgrade gastric lymphomas, suggesting its role in high-grade transformation. In this study, polymerase chain reaction-single strand conformation polymorphism (PCR-SSCP) analysis for bcl-6 primer was performed in order to ascertain the molecular mechanisms of bcl-6 protein expression in primary gastric lymphomas. A total 31 cases of gastric lymphoma were classified into low-grade gastric lymphomas of MALT type $(n=13)$, high-grade gastric lymphomas of MALT type $(n=6)$ and gastric diffuse large B-cell lymphomas $(n=12)$. Bcl-6 mutations were observed in 11 of $13(84.6 \%)$ low-grade gastric lymphomas of the MALT type and in 8 of $12(66.7 \%)$ diffuse large B-cell gastric lymphomas. In 6 cases of the high-grade gastric lymphomas of the MALT type, both the low- and high-grade components demonstrated the same frequency $(3 / 6,50 \%)$ of $\mathrm{mu}$ tations. The tissue obtained from the marginal zone of Peyer's patch by microdissection technique revealed no bcl-6 mutations by the PCR-SSCP analysis. These findings suggest that the acquisition process of bcl-6 mutations by the marginal zone cells may be involved in the lymphomagenesis of the stomach, but our data does not explain the reason

Copyright (C) 2001 by The United States and Canadian Academy of Pathology, Inc.

VOL. 14, NO. 5, P. 410, 2001 Printed in the U.S.A.

Date of acceptance: January 11, 2001.

Address reprint requests to: Jai Hyang Go, M.D., Department of Pathology, Dankook University College of Medicine, 16-5 Anseo-dong, Cheonan, Chungnam, 330-715, Korea; e-mail: jaihyang@yahoo.co.kr; fax: 82-41-561-9127. why bcl-6 protein is expressed only in high-grade gastric lymphomas.

KEY WORDS: Bcl-6, Lymphomagenesis, Molecular mechanism, Primary lymphoma, Stomach.

Mod Pathol 2001;14(5):410-414

Molecular studies such as polymerase chain reaction enable early detection of low-grade gastric lymphoma of the mucosa associated lymphoid tissue (MALT) type, previously regarded as lymphoid hyperplasia or pseudolymphoma, in minute specimens such as endoscopic biopsy tissues $(1,2)$. In this respect, the incidence of low-grade gastric lymphomas may be actually higher than that of highgrade gastric lymphomas in contrast to the previous studies that reported a higher incidence of high-grade gastric lymphomas. Because high-grade gastric lymphomas were more frequently detected clinically than low-grade tumors, it has been suggested that many of the low-grade tumors do not progress to high-grade lesions. Although there have been no prospective studies on the incidence of high-grade transformation of gastric lymphomas of the MALT type, some studies using archival materials have demonstrated that a significant proportion of high-grade gastric lymphomas were associated with areas of low-grade gastric lymphomas and that many genes, such as p53, bcl-2 and c-myc, were involved in the high-grade transformation (3, $4,5)$.

The bcl-6 gene was identified by virtue of its involvement in the chromosomal translocations affecting chromosome 3q27 in diffuse large cell lymphoma (DLCL). The same gene was then found to be rearranged in $40 \%$ of DLCL and $5 \%$ to $10 \%$ of follicular lymphomas (FL), including cases with cytogenetically normal 3q27. The rearrangement breakpoints cluster within a 4 -kb region spanning the bcl-6 promoter sequences and the first noncoding exon, and results in the fusion of bcl-6 coding sequences (exons 2-10) to heterologous promotors from other chromosomes (6). These alterations lead 
to the production of chimeric transcripts which encode for normal bcl-6 proteins, suggesting that the functional consequences of these translocations are the deregulation of bcl- 6 expression by promotor substitution (7). Bcl-6 rearrangements are associated with a subset of DLCL characterized by extranodal presentations and favorable outcomes (8).

Bcl-6 can be assigned to the Kruppel-like subfamily of zinc finger proteins, and may function as a DNA binding transcription factor that regulates organ development and tissue differentiation (9). By Northern blot analysis and immunohistochemistry, the expression of bcl- 6 was detected in mature B-cells but not in pro-B-cells, plasma cells, T cells, or other hematopoietic cells. This selective expression suggests that bcl- 6 may play a role in the control of normal B-cell differentiation and lymphoid organ development $(9,10,11)$. Zinc finger encoding genes are plausible candidate oncogenes, and terminal differentiation of hematopoietic cells is associated with the down regulation of these genes. It is conceivable that expression of bcl-6, caused by chromosomal rearrangements, interferes with normal B-cell differentiation or prevents postgerminal center differentiation, thereby contributing to the abnormal lymph node architecture typifying DLCL $(6,9)$.

In malignant lymphomas, follicular lymphomas constantly express the bcl- 6 protein, irrespective of gene rearrangements. In DLCL, bcl- 6 protein expression is more variable, and a correlation between protein expression and bcl- 6 rearrangement has not yet been found (12). Because the bcl-6 expression is more frequently observed than anticipated by cytogenetic and Southern blot analysis, other mechanisms of gene activation such as point mutation or deletion are considered to be involved $(12,13,14)$. Recent studies revealed frequent mutation of the bcl- 6 gene in the 5 ' noncoding region $(15,16)$, but not in the coding region (17) in malignant lymphomas. Bcl-6 mutations are also frequently found in the neoplastic counterparts of germinal center cells, including DLCL and FL, as well as the postgerminal center origin tumor (multiple myeloma) $(7,18)$. Bcl-6 gene rearrangement and protein expression have not been demonstrated in low-grade marginal zone lymphomas $(19,20)$. However, recent papers reported that bcl- 6 protein was identified in high-grade, but not in low-grade, gastric MALT lymphomas $(21,22)$, suggesting the role of bcl-6 in the high-grade transformation as p53. In this study, we performed PCR-SSCP analysis of the bcl-6 gene 5 ' noncoding region in order to discover the underlying molecular mechanism of bcl-6 protein overexpression in primary gastric lymphomas.

\section{MATERIALS AND METHODS}

\section{Materials}

Paraffin-embedded tissue blocks from 31 cases of gastric lymphomas were retrieved from the Department of Pathology, Yonsei University College of Medicine and Department of Diagnostic Pathology, Samsung Medical Center, Sungkyunkwan University School of Medicine in Korea. The diagnosis of low-grade gastric lymphoma of the MALT type was based on the well-established histologic criteria described by Isaacson (23). Lymphomas composed only of large transformed cells resembling centroblasts or immunoblasts without low-grade components were diagnosed as diffuse large B-cell lymphomas, in contrast to high-grade gastric lymphomas of the MALT type which have both lowand high-grade components. Paraffin tissue blocks from five cases of Peyer's patches and one case of non-neoplastic gastric mucosa, obtained from a resection specimen for high grade lymphoma, were also retrieved as a control.

\section{Microdissection and DNA Extraction}

After examination of hematoxylin-eosin stained slides, the tumor areas were trimmed from the representative sections. Genomic DNA was extracted from $10 \mu \mathrm{m}$ thick sections of formalin-fixed, paraffin-embedded tissues as previously described (24). In two cases, which contained an intermixture of high- and low-grade tumors, $5 \mu \mathrm{m}$ thick sections from paraffin blocks were dewaxed in xylene followed by rinses in ethanol, hematoxylin staining and air drying. The desired areas were obtained by microdissection using 30 gauge needles under a light microscope. Therefore, only areas of the tumor devoid of reactive germinal centers were sampled for this study. The marginal zone cells from Peyer's patch were also microdissected (Fig. 1).

\section{Polymerase Chain Reaction-Single Strand Conformation Polymorphism (PCR-SSCP) of the Bcl-6 Gene}

The 5' noncoding region of the bcl-6 gene was amplified by PCR reactions using the previously published primer sets (E1.7, E1.8, E1.10, E1.11, and E1.12) (15). The PCR reaction mix consisted of $1 \mu \mathrm{l}$ DNA extract, $4.5 \mathrm{~mm} \mathrm{MgCl}_{2}, 200 \mu \mathrm{mol}$ dNTP, 50 pmol of each primer, $10 \mathrm{~mm}$ Tris- $\mathrm{HCl}$ (pH 8.3), 50 $\mathrm{mm} \mathrm{KCl}$, and $1.25 \mathrm{U}$ Taq polymerase in a total volume of $50 \mu \mathrm{l}$. Amplification was performed on a thermocycler (Perkin Elmer, Norwalk, CT, U.S.A), comprising 30 cycles of $94^{\circ} \mathrm{C}$ for 30 seconds, $60^{\circ} \mathrm{C}$ for 30 seconds and $72^{\circ} \mathrm{C}$ for 30 seconds. PCR products $(3 \mu \mathrm{l})$ were checked for yield and size on $1 \%$ agarose gels before further analysis. A ten $\mu$ l PCR 


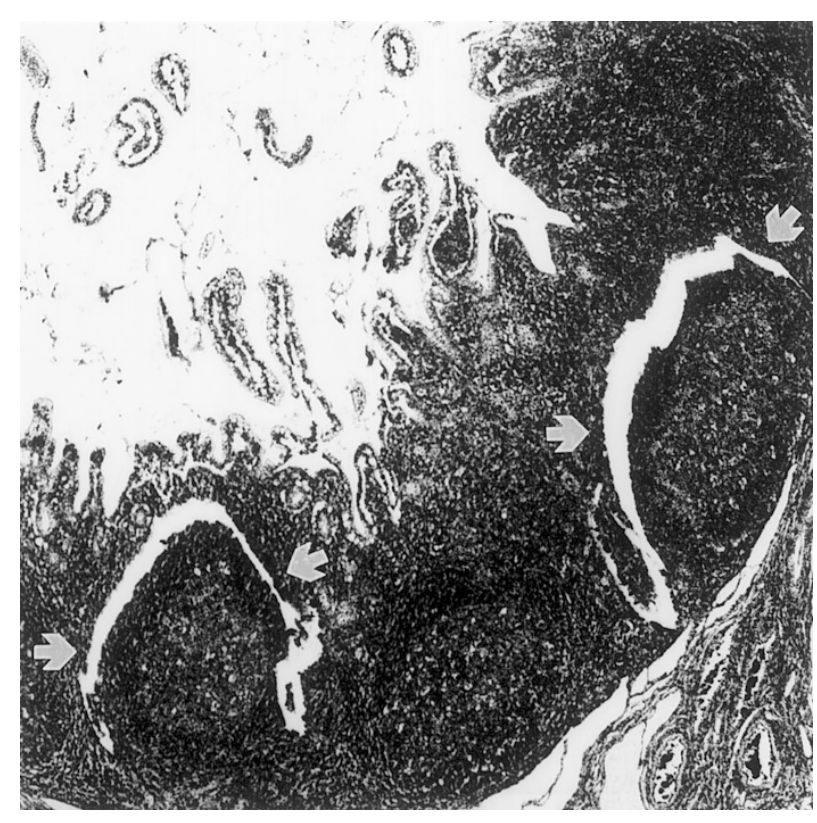

FIGURE 1. Microdissection of marginal zone cells (arrows) in Peyer's patch.

product was mixed with $1 \mu \mathrm{l}$ of alkaline denaturating solution and cooled with ice. They were then subjected to electrophoresis on a $10 \%$ polyacrylamide gel at $200 \mathrm{~V}$ for $4 \mathrm{hrs}$. The gel was then fixed with ethidium bromide for 10 minutes and observed using a UV transilluminator. The placental tissue was used as the negative control.

\section{RESULTS}

31 cases of primary gastric lymphomas were included in this study. 13 were low-grade gastric lymphomas of the MALT type and 18 were high-grade B-cell lymphomas, including 6 cases of high-grade gastric lymphomas of the MALT type and 12 cases of diffuse large B-cell gastric lymphomas.

The primary gastric lymphomas tested in this study displayed a total of 61 PCR-SSCP variants (Fig. 2). These variants were present in 11 out of 13 low-grade gastric lymphomas of the MALT type and in 8 out of 12 diffuse large B-cell gastric lymphomas. Among high-grade gastric lymphomas having both low- and high-grade components, 3 out of 6 low-grade areas and 3 out of 6 high-grade areas showed these variants (Table 1). Among 25 mutated cases, 17 cases displayed 2 or more variant fragments. The PCR-SSCP variants were most frequently detected in the fragment E1.7, irrespective of the grade. The microdissected marginal zone cells from Peyer's patch did not show any abnormal bands in the 5 cases tested. The normal gastric mucosa used as a control had reactive lymphoid follicles and showed abnormally shifted bands. The placental tissue did not show any mutation.
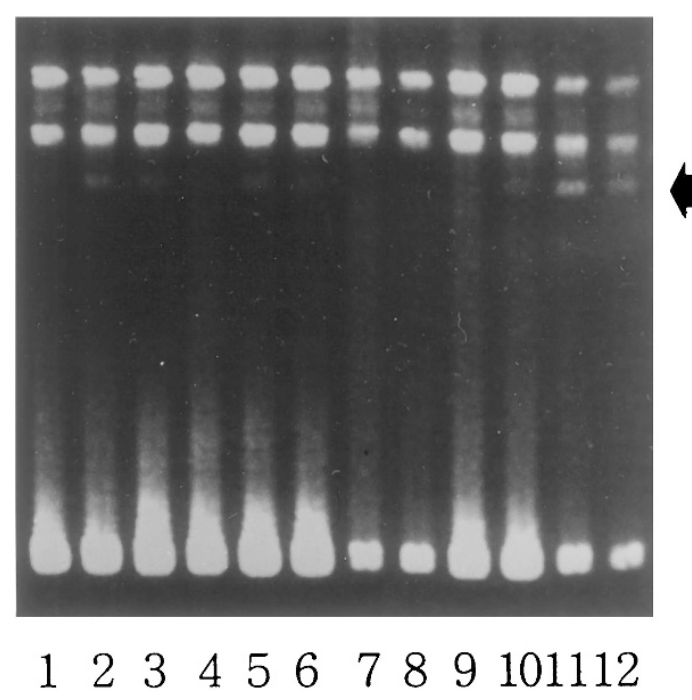

FIGURE 2. PCR-SSCP analysis for E 1.7 primer of bcl- 6 in gastric lymphomas. Many cases of low- and high-grade lymphomas showed abnormally shifted bands (arrow). Lanes 2, 3, 6, 9, 11: low-grade MALT lymphomas; Lanes 1, 4, 5, 7, 8, 10, 12: high-grade lymphomas.

TABLE 1. Frequencies of bcl-6 Mutation in Primary Gastric Lymphomas

\begin{tabular}{lc}
\hline \multicolumn{1}{c}{ Type } & $\begin{array}{c}\text { Mutated Cases/ } \\
\text { Tested Cases (\%) }\end{array}$ \\
\hline Low-grade lymphomas of MALT type & $11 / 13(84.6)$ \\
High-grade lymphomas of MALT type & $3 / 6(50.0)$ \\
Low-grade components & $3 / 6(50.0)$ \\
High-grade components & $8 / 12(66.7)$ \\
Diffuse large B-cell lymphomas & \\
\hline
\end{tabular}

\section{DISCUSSION}

Previous studies revealed neither bcl-6 gene rearrangements nor protein expression in low-grade marginal zone lymphomas $(19,20)$, and Southern blot analysis on 3 cases of high-grade and 2 cases of low-grade gastric lymphomas also demonstrated no bcl-6 gene rearrangements (25). However, bcl-6 protein expression was reported in high-grade MALT lymphomas of the stomach $(21,22)$. Therefore, it is speculated that bcl-6 may be involved in the high-grade transformation of gastric lymphomas by mechanisms other than gene rearrangement.

Recent studies have suggested that the bcl-6 gene may be altered by somatic mutations clustering within the 5' noncoding regions of this gene. These mutations are found in cases displaying either normal or rearranged bcl- 6 alleles, indicating their independence of chromosomal rearrangement. The sequences affected by these mutations are adjacent to the bcl-6 promotor region and overlap with the major cluster of chromosomal breakpoint (15). The mutation frequency is more than $70 \%$ in DLCL, which is much higher than that of rearrangement (7), and the high frequency, tumor specificity and location in the proximity of bcl-6 regulatory regions 
of these mutations suggest that these genetic lesions may play a role in lymphomagenesis (16).

Bcl-6 mutations of the 5' noncoding region are restricted to neoplasms derived from germinal center cells (DLCL and FL) or postgerminal center cells (multiple myeloma) and represent a histogenetic marker of germinal center transit $(18,26)$. Several recent studies reported bcl-6 mutation in normal germinal center B-cells, but not in naive B cells, and suggested bcl-6 mutations represented the effect of the IgV hypermutation process acting on non-Ig genes $(18,26)$. Bcl-6 mutation was not found in the microdissected mantle zone B cells (26), but mutation analysis from normal marginal zone cells has never been performed.

Bcl-6 mutation is detectable in 60 to $73 \%$ of primary gastric diffuse large B-cell lymphomas, in contrast to $22 \%$ of primary nodal large B-cell lymphomas (27). In low-grade MALT lymphoma, the results of investigations on bcl-6 mutations are variable. In one study, bcl- 6 mutations were found in 2 out of 4 cases (28), but in another study, mutations were absent from all 16 low-grade cases tested (29). In our study, bcl-6 mutations were observed in 11 out of 13 low-grade gastric lymphomas of the MALT type and in 3 out of 6 low-grade components of high-grade gastric lymphomas of the MALT type. High-grade components of high-grade gastric lymphomas show the same frequency of bcl- 6 mutations $(3 / 6,50 \%)$ as in low-grade components, and 8 out of 12 diffuse large B-cell gastric lymphomas demonstrated bcl-6 mutations. However, the microdissected marginal zone cells from Peyer's patch did not show any abnormally shifted bands in the 5 samples tested. Therefore, it can be concluded from our data that the acquisition of bcl- 6 mutations by marginal zone cells may be involved in the lymphomagenesis of primary gastric lymphomas, but not in high-grade transformation. However, an alternative hypothesis can be considered: that the lymphoma cells acquire mutations as they traffic through the germinal centers, and the bcl-6 mutation has no role in lymphomagenesis and simply represents a histogenetic marker of germinal center transit. Because lymphomas of the MALT type show intimate interactions of tumor cells with lymphoid follicles, where tumor cells sometimes show high-grade transformation (25), it can also be speculated that the germinal center microenvironment induces bcl-6 protein overexpression by mechanisms other than mutations. Studies involving in vitro transformation systems and in vivo expression in transgenic mice are warranted to investigate these hypotheses.

\section{REFERENCES}

1. Savio A, Franzin G, Wotherspoon AC, Zamboni G, Negrini R, Buffoli $\mathrm{F}$, et al. Diagnosis and posttreatment follow up of Helicobacter pylori-positive gastric lymphoma of mucosa- associated lymphoid tissue: histology, polymerase chain reaction, or both? Blood 1996;87:1255-60.

2. Isaacson PG, Norton AJ. Malignant lymphoma of the gastrointestinal tract. In: Isaacson PG, Norton AJ, editors. Extranodal lymphomas. New York: Churchill Livingstone; 1994: 38-9.

3. Nakamura S, Akazawa K, Kinukawa N, Yao T, Tsueyoshi M. Inverse correlation between the expression of bcl-2 and p53 proteins in primary gastric lymphoma. Hum Pathol 1996;27: 225-33.

4. Du M, Diss TC, Xu C, Peng H, Isaacson PG, Pan L. Ongoing mutation in MALT lymphoma immunoglobulin gene suggests that antigen stimulation plays a role in the clonal expansion. Leukemia 1996;10:1190-7.

5. van Krieken JH, Raffeld M, Raghoebier S, Jaffe ES, van Ommen GJ, Kluin PM. Molecular genetics of gastrointestinal non-Hodgkin's lymphomas: unusual prevalence and pattern of c-myc rearrangements in aggressive lymphomas. Blood 1990;76:797-800.

6. Cattoretti G, Chang C-C, Cechova K, Zhang J, Ye BH, Falini B, et al. Bcl-6 protein is expressed in germinal-center B cells. Blood 1995;86:45-53.

7. Migliazza A, Martinotti S, Chen W, Fusco C, Ye BH, Knowles $\mathrm{DM}$, et al. Frequent somatic hypermutation of the 5' noncoding region of the BCL6 gene in B-cell lymphoma. Proc Natl Acad Sci U S A 1995;92:12520-4.

8. Offit K, Lo Coco FL, Louie DC, Parsa NZ, Leung D, Portlock $\mathrm{C}$, et al. Rearrangement of the bcl- 6 gene as a prognostic marker in diffuse large-cell lymphoma. N Engl J Med 1994; 331:74-80.

9. Ye BH, Lista F, Lo Coco F, Knowles DM, Offit K, Chaganti RSK, et al. Alterations of a zinc finger-encoding gene, BCL-6, in diffuse large-cell lymphoma. Science 1993;262:747-50.

10. Onizuka T, Moriyama M, Yamochi T, Kuroda T, Kazama A, Kanazawa N, et al. BCL-6 gene product, a 92- to $98-\mathrm{kD}$ nuclear phosphoprotein, is highly expressed in germinal center B cells and their neoplastic counterparts. Blood 1995; 86:28-37.

11. Flenghi L, Ye BH, Fizzotti M, Cattoretti G, Venturi S, Pacini R, et al. A specific monoclonal antibody (PG-B6) detects expression of the BCL-6 protein in germinal center B cells. Am J Pathol 1995;147:405-11.

12. Pittaluga S, Ayoubi TAY, Wlodarska I, Stul M, Cassiman J-J, Mecucci C, et al. Bcl-6 expression in reactive lymphoid tissue and in B-cell non-Hodgkin's lymphomas. J Pathol 1996;179: $145-50$.

13. Nakamura Y, Miki T, Kawamata N, Hirosawa S, Saito K, Enokihara $\mathrm{H}$, et al. Biallelic DNA rearrangements and deletions within the bcl-6 gene in B-cell non-Hodgkin's lymphoma. Br J Haematol 1995;90:404-8.

14. Nakamura Y, Miki T, Miura I, Hashimoto K, Miura A, Akimoto K, et al. Internal DNA deletion within the bcl-6 gene on untranslocated chromosome in non-Hodgkin's lymphoma with 3q27 abnormality. Leukemia 1996;10:658-61.

15. Gaidano G, Carbone A, Pastore C, Capello D, Migliazza A, Gloghini A, et al. Frequent mutation of the 5' noncoding region of the BCL- 6 gene in acquired immunodeficiency syndrome-related non-Hodgkin's lymphomas. Blood 1997; 89:3755-62.

16. Capello D, Carbone A, Pastore C, Gloghini A, Saglio G, Gaidano G. Point mutations of the BCL-6 gene in Burkitt's lymphoma. Br J Haematol 1997;99:168-70.

17. Otsuki T, Yano T, Clark HM, Bastard C, Kerckaert JP, Jaffe ES, et al. Analysis of LAZ3 (BCL-6) status in B-cell nonHodgkin's lymphomas: results of rearrangement and gene expression studies and a mutational analysis of coding region sequences. Blood 1995;85:2877-84.

18. Pasqualucci L, Migliazza A, Fracchiolla N, William C, Neri A, Baldini L, et al. BCL-6 mutation in normal germinal center B 
cells: Evidence of somatic hypermutation acting outside Ig loci. Proc Natl Acad Sci U S A 1998;95:11816-21.

19. Ruppert JM, Kinzler KW, Wong AJ, Bigner SH, Kao F, Law ML, et al. The GLI-Kluppel family of human genes. Mol Cell Biol 1988;8:3104-13.

20. Flenghi L, Bigerna B, Fizzotti M, Venturi S, Pasqualcucci L, Pileri S, et al. Monoclonal antibodies PG-B6a recognize, respectively, a highly conserved and a Formol-resistant epitope on the human BCL-6 protein amino-terminal region. Am J Pathol 1996;148:1543-55.

21. Omonishi K, Yoshino T, Sakuma I, Kobayashi K, Moriyama M, Akagi T. Bcl-6 protein is identified in high-grade but not low-grade mucosa-associated lymphoid tissue lymphomas of the stomach. Mod Pathol 1998;11:181-5.

22. Lee JD, Takahashi K, editors. Proceedings of the fifth KoreanJapanese Lymphoreticular Workshop; 1997 Apr 25-26; Kyungju. Kyungju, Korea: Hematolymphoreticular Study Group. The Korean Society of Pathologists.

23. Isaacson PG, Norton AJ. Malignant lymphoma of the gastrointestinal tract. In: Isaacson PG, Norton AJ, editors. Extranodal lymphomas. New York: Churchill Livingstone; 1994:1741.
24. Weight DK, Manos MM. Sample preparation from paraffinembedded tissues. In: Innis MA, Gelfand DH, Sninsky JJ, White TJ, editors. PCR protocols: a guide to methods and applications. San Diego, CA: Academic; 1990:153-8.

25. Go JH. Bcl-6 gene abnormalities and protein expression in primary gastric lymphomas. 2000, Doctoral Dissertation, The Graduate School, Yonsei University, Seoul, Korea.

26. Peng H, Du M, Koulis A, Aiello A, Dogan A, Pan L, et al. Nonimmunoglobulin gene hypermutation in germinal center B cells. Blood 1999;93:2167-72.

27. Liang R, Chan WP, Kwong YL, Chan ACL, Xu WS, Au WY, et al. Bcl-6 gene hypermutations in diffuse large B-cell lymphoma of primary gastric origin. Br J Haematol 1997;99:66870.

28. Liang R, Chan WP, Kwong YL, Chan ACL, Xu WS, Srivastava G. Mutation of the 5' noncoding region of the bcl-6 gene in low-grade gastric lymphoma of the mucosa-associated lymphoid tissue. Cancer Genet Cytogenet 1998;102:110-3.

29. Gaidano G, Capello D, Gloghini A, Fassone L, Vivenza D, Ariatti C, et al. Frequent mutation of bcl-6 proto-oncogene in high grade, but not low grade, MALT lymphomas of the gastrointestinal tract. Haematologica 1999;84:582-8. 